\title{
The Spirit and Its Letter
}





\section{The Spirit and Its Letter}

Traces of Rhetoric in Hegel's Philosophy of Bildung

*

John H. Smith

Cornell University Press

Ithaca and London 


\section{Cornell University Press gratefully acknowledges a GRANT FRoM the ANDREW W. Mellon Foundation}

THAT AIDED IN BRINGING THIS BOOK TO PUBLICATION.

\section{Copyright (C) 1988 by Cornell University}

All rights reserved. Except for brief quotations in a review, this book, or parts thereof, must not be reproduced in any form without permission in writing from the publisher. For information, address Cornell University Press, 124 Roberts Place, Ithaca, New York 14850.

First published 1988 by Cornell University Press.

International Standard Book Number o-8014-2048-2 Library of Congress Catalog Card Number 87-4796o

Librarians: Library of Congress cataloging information appears on the last page of the book.

The paper in this book is acid-free and meets the guidelines for permanence and durability of the Committee on Production Guidelines for Book Longevity of the Council on Library Resources. 
For Jane and Julian 
